that the projectile would be deflected upwards by the resistance of the air, so as to increase the elevation for which the gun was laid. This was named "kite-like action" in England, and Didion remarked that there would be a considerable deviation of the projectile "tant dans le plan vertical, que dans le plan horizontal"(Traite, xiii. I860). Suppose now that the range $r$ and the time of flight $t$, for an elevation $\alpha$, have been carefully calculated. Then from the range table of the same gun, corresponding to same range $r$, find $t^{\prime}$ the time of flight, and $a^{\prime}$ the elevation. Then if $t=t^{\prime}$ the coefficients of resistance giving the required time and range, are correct, and $\alpha-a^{\prime}$ is due to kitelike action. Thus, using the range table of the 4-inch B.L. gun : $v=1900$ f.s. ; $w=25$ lbs. ; $\alpha=12^{\circ}$; and $\kappa=0.97$.

$(\gamma)$

\begin{tabular}{lc|c|c|c}
\hline & Range. & Time of flight. & Elevation. \\
\hline Calculation & $\ldots$ & $\begin{array}{l}r=5666 \text { yards } \\
\text { R. Table }\end{array}$ & $\begin{array}{r}t=17^{\prime \prime} \cdot 008 \\
t^{\prime}=16^{\prime \prime} \cdot 964\end{array}$ & $\begin{array}{r}\alpha=12^{\circ} 0^{\prime} \\
a^{\prime}=11^{\circ} 26^{\prime}\end{array}$ \\
\hdashline Difference & $\ldots$ & 0 & $t-t^{\prime}=0^{\prime \prime} \cdot 044$ & $\alpha-\alpha^{\prime}=0^{\circ} 34^{\prime}$
\end{tabular}

Here for a range of over three miles, the calculated and ob served times of flight, from point to point, differ by only $0^{\prime \prime} \cdot 044$. a negligible quantity. The resistance of the air must therefore have increased the elevation, for which the gun was laid, by $a-a^{\prime}=34^{\prime}$, due to jump and kite-like action, for an elevation of the gun of $11^{\circ} 26^{\prime}$. The whole range table of the 4 -inch B.L. gun was thus treated in 1892 (NAture, No. II90). These calculations have recently been repeated for elevations $7^{\circ}$ to $20^{\circ}$, and published in my Second Supplement, where all the leading steps in the calculation of the ranges, \&c., have been given. It was then found that when an elevation of $7^{\circ}$ is given to the gun, $2 \mathrm{I}^{\prime}$ is added to the elevation by kite-like action, so that $7^{\circ}+2 I^{\prime}$ must be used for the elevation when it is required to calculate the range and time of flight for an elevation $7^{\circ}$ of the gun. The elevation of the gun is given in degrees below, and the addition thereto made by kite-like action and jump is given in minutes, $7^{\circ}+21^{\prime}, 8^{\circ}+23^{\prime}, 9^{\circ}+26^{\prime}, 10^{\circ}+29^{\prime}, 11^{\circ}+33^{\prime}, 12^{\circ}+38^{\prime}, 13^{\circ}+45^{\prime}$, $14^{\circ}+53^{\prime}, 15^{\circ}+63^{\prime}, 16^{\circ}+74^{\prime}, 17^{\circ}+86^{\prime}, 18^{\circ}+98^{\prime}$.

From the results of calculations of range and time above referred to, I have deduced the following table :-

\begin{tabular}{|c|c|c|c|c|c|c|}
\hline \multirow{2}{*}{$\begin{array}{c}\text { Range. } \\
\text { Yards. }\end{array}$} & \multicolumn{3}{|c|}{ Time of Flight. } & \multicolumn{3}{|c|}{ Elevation. } \\
\hline & R.T. & Calculated. & Diff. & R.T. & Calculated. & Diff. \\
\hline 4000 & xо"49 & Io'35 & -0.14 & 621 & 632 & +11 \\
\hline 5000 & 14.30 & $14 \cdot 19$ & -0.11 & $90 \quad 12$ & 937 & +25 \\
\hline 6000 & 1840 & 18.51 & +0.11 & 1236 & 1318 & +42 \\
\hline 7000 & 23.50 & 23.59 & +0.09 & 1632 & 1759 & +87 \\
\hline
\end{tabular}

showing clearly that both range and time of flight-given by experiment and calculation-agree, when a proper allowance is made for jump and kite-like action.

From the fair application of all these tests, it appears that calculated and experimental ranges and times of flight agree perfectly well for all practical purposes. Hence the laws of resistance determined by me-the general tables published by me-and the adaptation by me of J. Bernoulli's method of calculating trajectories are all quite satisfactory. But care will be required not to make my methods responsible, in any way, for the disturbing effects of jump or of kite-like action. Consequently range tables cannot at present be prepared by calculation alone, but when obtained by experiment, they may be tested at any point by the method $(\gamma)$ already explained.

This chronograph might be used with great advantage to test the shooting qualities of all big guns. For this purpose the elongated projectiles should be provided with heads of similar forms. The charges used should be such as would give the velocity $v$, for which the gun is to be tested, near the middle screen. Fire each projectile through the equidistant screens till $n$ satisfactory rounds have been obtained. Calculate $\mathrm{K}_{v}{ }^{\prime}$, $\mathrm{K}_{v}^{\prime \prime}$, \&c., for each of these rounds. Then the approximate NO. I662, VOL. 64] value of $\mathrm{K}_{v}=\frac{\mathrm{I}}{n}\left(\mathrm{~K}_{v}{ }^{\prime}+\mathrm{K}_{v}{ }^{\prime \prime}+\& \mathrm{c}\right.$. $)$, and the mean error will be an indication of the steadiness imparted by the gun to its projectile, and so on for any number of guns. The shooting qualities of any guns could be compared for the velocity $v$, by simply comparing the numerical values of $\mathrm{K}_{v}$ given by each gun-the lower the numerical value of $\mathrm{K}_{v}$ the better the shooting. Target practice might be carried on simultaneously with these screen experiments. The best of the guns taken in South Africa should be brought home and tested in the manner above recommended.

August 1901.

F. BASHFORTH.

\section{Horn-feeding Larvæ.}

So far back as June, 1898 , you published in NATURE a short article from my pen dealing with "Horn-feeding Larvæ"; it opened up the question as to whether the larvæ of the insect I'inea vastella, Zell. = gigantella, Stn. = lucidella, WKr., fed on the horns of living animals. I mentioned at the time that Dr. Fitzgibbon, in 1856 , brought home from the Gambia two pairs of horns, one belonging to Kolus ellipsi. prymnus and the other to Oreas canna, which he had purchased from the natives; the horns were perforated by grubs enclosed in cases which projected abundantly from the surface of the horns, the blood at the base of the horns not having thoroughly dried up on them when brought to market.

Dr. Henry Strachan, of Lagos, wrote a letter, dated July 22 I 898 , which appeared in NATURE, and in that letter he stated that the living horns were attacked and infested with the larvæ, as cocoons and pupæ had been extracted from such horns within an hour of the killing of the animals owning them. This he states on the unimpeachable authority of an officer who made the observation.

During 1899, I900, and until July of this year, I have travelled very considerably in West Africa, having spent these years in Northern and Southern Nigeria, as well as Ashanti and the hinterland of the Gold Coast ; I have made close observation of many species of horned animals, and have spent many days with native big game hunters. I have seen many cases in which the horns of dead animals have been infested with the larvæ of the Tineidae, but have never met with it in those of living animals. The natives with whom $I$ have been associated, who are keen hunters and extremely keen observers, assure me they have never seen any protuberances containing grubs on the horns of living animals. During our campaign in Ashanti, questioned officers who came with troops from all parts of the West Coast as well as the East Coast of Africa; also some from Uganda and the Lakes: they all unhesitatingly say that they have never seen cocoons on living animals, although well acquainted with them on the horns of dead animals. Dr. Fitzgibbon's statement stood alone until Dr. Strachan's letter appeared. I venture to suggest that the point still remains sub judice.

August 30 .

\section{NEW GARDEN PLANTS: A STUDY IN EVOLUTION.}

THE appellation "new garden-plants" is rather puzzling to those who are neither botanists nor gardeners, and, indeed, it is used with somewhat different significations by both these classes of experts. Considering that not the least of the many services rendered by the Royal Gardens, Kew, is the annual publication, as an appendix to the Kew Bulletin, of a list of "new garden plants," some explanation of what is meant by this designation may not be without interest. Let us take an illustration. The maidenhair tree, Ginkgo biloba, was in reality introduced into our gardens in 1750 or thereabouts. But let us suppose for our present purpose that it was introduced only in this year of grace rgor. Would it in that case have any right to be considered a " new plant"? If we look on it as the direct lineal descendant of a tree that grew in Greenland in Miocene times and had its ancestry still further back in the Oolitic period, we could hardly consider it as "new." The only novelty about it would be its introduction into gardens. Similarly, 